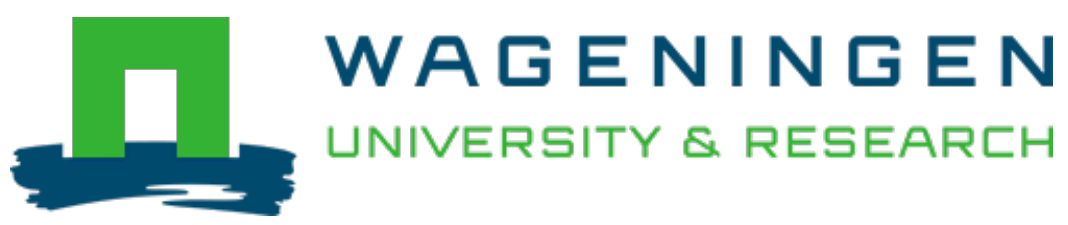

\title{
Quality, safety, biofunctionality and fermentation control in soya
}

Advances in Fermented Foods and Beverages: Improving Quality, Technologies and Health Benefits

Nout, M.J.R.

https://doi.org/10.1016/B978-1-78242-015-6.00018-9

This publication is made publicly available in the institutional repository of Wageningen University and Research, under the terms of article $25 \mathrm{fa}$ of the Dutch Copyright Act, also known as the Amendment Taverne. This has been done with explicit consent by the author.

Article $25 \mathrm{fa}$ states that the author of a short scientific work funded either wholly or partially by Dutch public funds is entitled to make that work publicly available for no consideration following a reasonable period of time after the work was first published, provided that clear reference is made to the source of the first publication of the work.

This publication is distributed under The Association of Universities in the Netherlands (VSNU) 'Article $25 \mathrm{fa}$ implementation' project. In this project research outputs of researchers employed by Dutch Universities that comply with the legal requirements of Article $25 \mathrm{fa}$ of the Dutch Copyright Act are distributed online and free of cost or other barriers in institutional repositories. Research outputs are distributed six months after their first online publication in the original published version and with proper attribution to the source of the original publication.

You are permitted to download and use the publication for personal purposes. All rights remain with the author(s) and / or copyright owner(s) of this work. Any use of the publication or parts of it other than authorised under article $25 \mathrm{fa}$ of the Dutch Copyright act is prohibited. Wageningen University \& Research and the author(s) of this publication shall not be held responsible or liable for any damages resulting from your (re)use of this publication.

For questions regarding the public availability of this publication please contact openscience.library@wur.nl 


\section{Quality, safety, biofunctionality and fermentation control}

in soya

R. Nout

Wageningen University, Wageningen, The Netherlands

\subsection{Introduction}

Soya beans (Glycine max (L.)) are the most important source of plant-derived dietary protein, oil and biofunctional components. In various publications, the spelling differs from soybean, soya bean, soya, soy, etc. In this chapter, we will keep to soya, except when specific mention is made of the beans to distinguish them from other parts of the plant.

Soya is well known as a source of human and animal nutrition (American Soybean Association, 2012a), as well as a raw material for industrial purposes. A range of commercial products is prepared from soya as the starting ingredient (American Soybean Association, 2012b). In this chapter, we will limit the focus to the significance of soya to the human diet and health.

For food uses, soya derivatives are used as ingredients in a wide range of consumer foods. Examples are soya oil, lecithin, soya flour in bakery products, soya protein isolates, etc. This chapter will not deal with these ingredients, but rather focus on food products made by fermentation processes.

The region of origin of soya fermentation is Asia, and in particular Southeast Asia and East Asia. It is not only the widespread use of soya that makes this region unique, but also the use of filamentous fungi in food preparation. Whereas in many other cultures, filamentous fungi (moulds) are associated with spoilage and even toxicity - caused by mycotoxins - the Asian household has discovered the capability of certain filamentous fungi to produce flavour and texture that form the basis of nutritious and savoury foods and condiments. In this chapter we will discover some of these wonderful products.

\subsection{Fermented soya products}

A range of fermented soya food products is known (Chen et al., 2012), and Table 18.1 illustrates some important representatives that will be discussed in this chapter. There are several ways to distinguish fermented soya products, for example, by their consistency, their salt content or the type of microorganisms used for their fermentation. In Table 18.1, the products are listed according to consistency: sauces are liquid, pastes are semi-solid and another group comprises solid or firm food products. The salt content depends very much on the manufacturing process. Salt has been used traditionally 
Table 18.1 Overview of some major fermented soya foods and condiments

\begin{tabular}{|c|c|c|c|c|}
\hline Group & Name & Origin & Salt added & Reference \\
\hline \multirow[t]{2}{*}{ Sauces } & Shoyu & Japan & Yes & $\begin{array}{l}\text { Aidoo et al. } \\
\text { (2006) }\end{array}$ \\
\hline & Kecap & Indonesia & Yes & $\begin{array}{l}\text { Röling et al. } \\
\text { (1996) }\end{array}$ \\
\hline \multirow[t]{4}{*}{ Pastes } & Miso & Japan & Yes & $\begin{array}{l}\mathrm{Li} \text { and Ma } \\
\text { (2003), Kim, } \\
\text { Hong et al. } \\
\text { (2010) }\end{array}$ \\
\hline & Doujiang & China & Yes & $\begin{array}{l}\text { Lim (1991), } \\
\text { Kim, Hong } \\
\text { et al. (2010) }\end{array}$ \\
\hline & Doenjang & Korea & Yes & $\begin{array}{l}\text { Kim et al. } \\
\text { (2009) }\end{array}$ \\
\hline & Chongkukjang & Korea & Yes & $\begin{array}{l}\text { Nout et al. } \\
\quad(2014)\end{array}$ \\
\hline \multirow[t]{5}{*}{$\begin{array}{l}\text { Solid-fermented } \\
\text { soya foods }\end{array}$} & Natto & Japan & No & $\begin{array}{l}\text { Murooka and } \\
\text { Yamshita } \\
(2008)\end{array}$ \\
\hline & Kinema & $\begin{array}{l}\text { Nepal and } \\
\text { India }\end{array}$ & No & $\begin{array}{c}\text { Sarkar et al. } \\
\text { (1994) }\end{array}$ \\
\hline & Tempe & Indonesia & No & $\begin{array}{l}\text { Nout and Kiers } \\
\quad(2005)\end{array}$ \\
\hline & Sufu & China & Yes & $\begin{array}{l}\text { Han, } \\
\text { Rombouts } \\
\text { et al. (2001) }\end{array}$ \\
\hline & Douchi & China & Yes & $\begin{array}{l}\text { Zhang et al. } \\
\text { (2007) }\end{array}$ \\
\hline
\end{tabular}

for preservation purposes and, of course, for taste. Salt continues to play an important role in the process because some maturation steps take several weeks or months at ambient temperatures and the product needs to be protected against pathogenic or toxin-producing spoilage microorganisms. Salt also facilitates some enzymic conversions that enhance digestibility and flavour development.

\subsubsection{Soya sauce}

Soya sauces are found all over South and East Asia, and local differences exist in process conditions and ingredients used, catering for the preferences and expectations of the consumer (Chen et al., 2012). Japanese soya sauces have been exported all over the world, and their production was industrialized and mechanized more than 50 years ago. Soya sauces are used for cooking, for marinades and as a savoury ingredient. In principle, Japanese soya sauce or shoyu is made from soya beans, wheat, water, salt and microorganisms. The essential steps in the process are outlined 


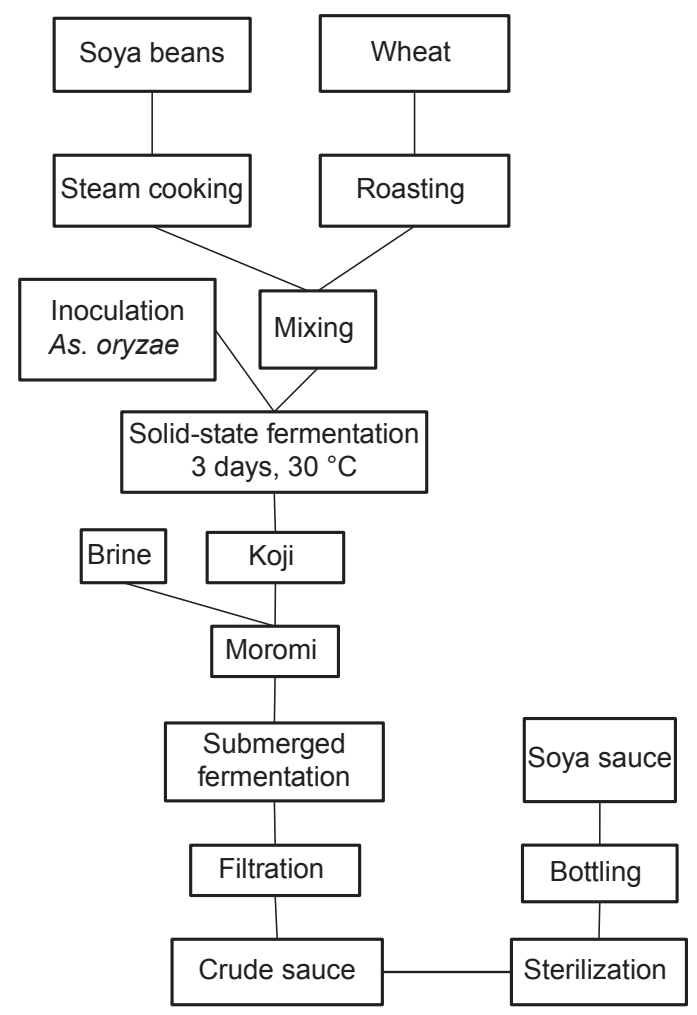

Figure 18.1 Soya sauce production process. A mixture of cooked soya beans and crushed roasted wheat is inoculated with Aspergillus oryzae and incubated to obtain koji. Koji is aged in brine to obtain crude soya sauce, which is filtered and bottled.

in Figure 18.1. Soya beans are cooked to facilitate their degradation by enzymes during later stages. The cooking can be done at ambient atmospheric pressure, but pressure cookers are used at industrial scale. Soya protein is denatured, moisture content is increased, and some undesirable components are inactivated. Major undesirable components of raw soya beans include the trypsin inhibitor, which is a protein that blocks soya digestion in the human gastrointestinal tract, and lipoxygenase, an enzyme that can generate bitter-tasting lipid derivatives during soaking of soya beans in water. Cooking thus improves digestibility and helps to avoid generating off-taste.

The objective is to allow a solid-state fermentation (SSF) of the cooked soya beans with filamentous fungi. However, the moisture content of the cooked soya beans is rather high for fungal SSF, and soya beans also lack fermentable carbohydrate that could serve as a source of carbon for fungi.

For that reason, the Japanese process includes wheat as an ingredient (Fukushima, 1989). Wheat kernels are roasted by hot air treatment, and coarsely milled to gritty particles. The roasting causes the wheat protein and starch to be accessible for enzymic degradation. The wheat grits are mixed with the cooked soya beans to achieve the optimum water activity for fungal SSF, and the mixture is inoculated with tane 
koji, a traditional powdered starter consisting of conidia of selected Aspergillus oryzae strains. Aspergillus oryzae is selected for vigorous growth and enzyme production, mainly proteases, carbohydrases, phosphatases and other enzymes. Inoculation rates usually are $10^{6}$ propagules per gram of soya-wheat mixture. After inoculation, incubation takes place at $30^{\circ} \mathrm{C}$ for 3 days, during which period the fungal mycelium grows and a start of sporulation becomes visible. When the moulded mixture turns yellowish-green because of the pigmented fungal conidia, the SSF has resulted in koji, a mass of partially degraded soya and wheat containing active hydrolytic enzymes.

The next step in the process is a submerged fermentation of koji particles in brine, a phase that is referred to as moromi. The brine has a salt concentration of about $20 \%$, and the ratio of koji to brine is approximately $1: 8$. In the moromi fermentation, which can take 6-12 months at temperatures around $15^{\circ} \mathrm{C}$, the solid soya and wheat particles are gradually broken down to water-soluble molecules such as amino acids, free fatty acids, saccharides, etc. As a result of the availability of easily assimilable carbon and nitrogen, opportunistic bacteria and yeasts will slowly develop. These are halotolerant microorganisms, so a rather specific mixed microbiota consisting of Tetragenococcus halophilus and Zygosaccharomyces rouxii usually predominates. Since these improve the taste by the formation of organic acids, esters and other flavour compounds, they are nowadays added to the moromi to ensure a constant and predictable fermentation outcome.

After the moromi fermentation, the raw sauce is obtained by filtration; the filtered sauce is pasteurized and bottled. Table 18.2 illustrates the chemical composition of soya sauce (Fukushima, 1989). It should be noted that of all nitrogen present, approximately half is present as amino nitrogen. This implies that the soya protein has been broken down to a very large extent into low-molecular-mass water-soluble compounds.

\subsubsection{Soya pastes}

Soya pastes have a semi-solid consistency, because they have been ground to a smooth paste. These pastes are used as a side-dish, or as soup ingredients to provide a savoury taste.

Table 18.2 Chemical composition of soya sauce

\begin{tabular}{|l|l|}
\hline & Content $(\mathbf{g} / \mathbf{1 0 0} \mathbf{~ m l})$ \\
\hline Water & 70 \\
Protein & 7.4 \\
Total nitrogen & 1.7 \\
Amino nitrogen & 0.83 \\
Crude lipid & 0.6 \\
Carbohydrate & 7.2 \\
Ash & 18.4 \\
NaCl & 16.8 \\
Sodium & 0.5 \\
Alcohol & 2.3 \\
pH & 4.7 \\
\hline
\end{tabular}




\subsubsection{Miso}

Miso is a paste made from moulded rice, cooked soya beans and salt (Shurtleff \& Aoyagi, 2001a; Wood, 1982). The principle of the manufacturing process is shown in Figure 18.2. A koji is prepared almost similar to the koji for soya sauce, using selected strains of As. oryzae. After mixing three parts koji, salt, and five parts steamed rice, the mixture is homogenized, packed and fermented for several months depending on consumers' demand. Some amount of previous miso is mixed with the mash and packed in a container for fermentation. Instead of adding previous miso, pure cultures of the yeast $Z$. rouxii can be added. Table 18.3 illustrates the major chemical constituents of miso. Miso is a good source of protein, minerals and B-vitamins.

\subsubsection{Doujiang}

Doujiang is a Chinese soya bean paste containing semi-solid and partially intact soybeans, made from soya beans, wheat, salt, potable water and naturally occurring/ cultivated microorganisms, sometimes with additional ingredients such as grains and/ or flour, Lactobacillus sp., distilled alcohol derived from agricultural products, sugars,

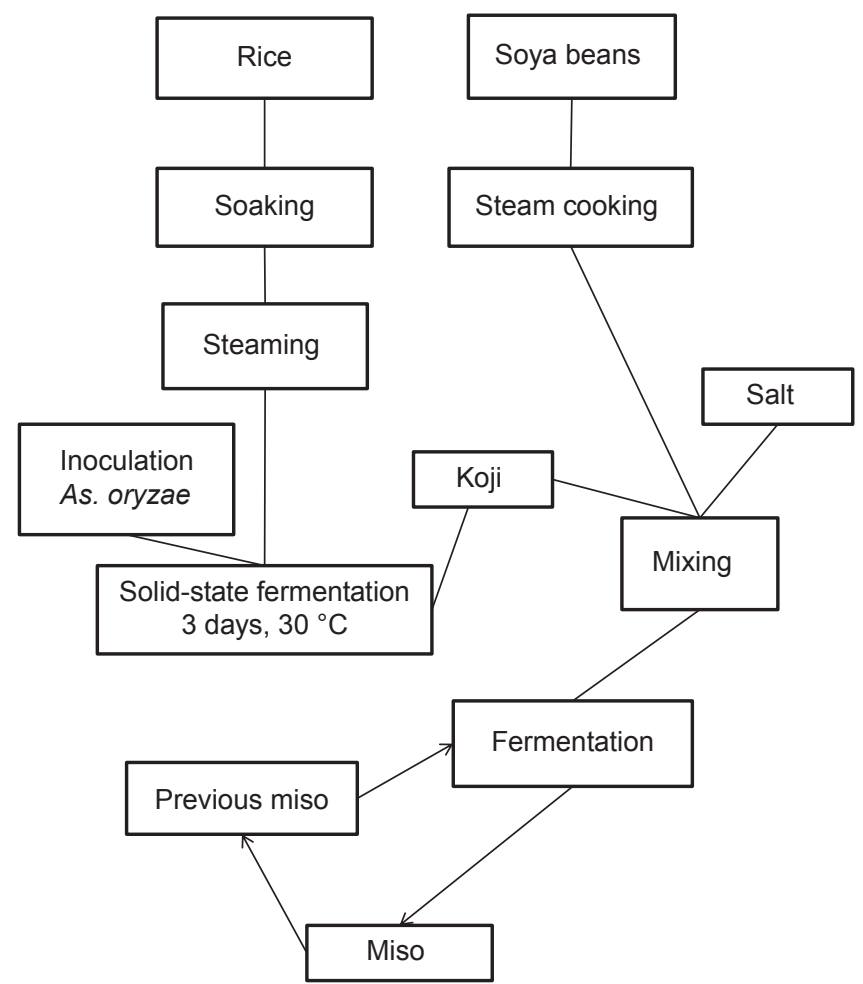

Figure 18.2 Miso process. Steamed rice is fermented with Aspergillus oryzae to obtain koji, which is mixed with cooked soya beans and salt for fermentation to obtain miso. 


\section{Table 18.3 Constituents of miso}

\begin{tabular}{|l|l|}
\hline Water $(\mathrm{g} / 100 \mathrm{~g})$ & 41.5 \\
Crude protein $(\mathrm{g} / 100 \mathrm{~g})$ & 11.8 \\
Crude lipid $(\mathrm{g} / 100 \mathrm{~g})$ & 6.1 \\
Carbohydrates $(\mathrm{g} / 100 \mathrm{~g})$ & 28.0 \\
Crude fibre $(\mathrm{g} / 100 \mathrm{~g})$ & 2.5 \\
Energy $(\mathrm{kJ} / 100 \mathrm{~g})$ & 865 \\
$\mathrm{Ca}(\mathrm{mg} / 100 \mathrm{~g})$ & 66 \\
$\mathrm{Fe}(\mathrm{mg} / 100 \mathrm{~g})$ & 2.74 \\
$\mathrm{Na}(\mathrm{mg} / 100 \mathrm{~g})$ & 3647 \\
$\mathrm{Zn}(\mathrm{mg} / 100 \mathrm{~g})$ & 3.32 \\
$\mathrm{Thiamin}(\mathrm{mg} / 100 \mathrm{~g})$ & 0.1 \\
$\mathrm{Riboflavin}(\mathrm{mg} / 100 \mathrm{~g})$ & 0.25 \\
Niacin $(\mathrm{mg} / 100 \mathrm{~g})$ & 0.86 \\
Vitamin $\mathrm{B}_{6}(\mathrm{mg} / 100 \mathrm{~g})$ & 0.22 \\
Folacin $(\mathrm{mg} / 100 \mathrm{~g})$ & 0.033 \\
\hline
\end{tabular}

Source: Data from Wood (1982) and Chen et al. (2012).

starch syrup and naturally flavoured raw materials (Kim, Lee, Park, \& Kim, 2010; Zhao et al., 2009). Raw soya beans are soaked, and steam cooked at $121^{\circ} \mathrm{C}$ for $20 \mathrm{~min}$. Wheat flour and cooked soya beans are mixed at a ratio of $2: 3$, cooled to $40^{\circ} \mathrm{C}$, and inoculated with As. oryzae starter, and allowed to ferment for 4 to 7 days. When fungal conidia appear, the mixture is mashed and immersed into brine, which is agitated weekly. The submerged fermentation can take up to 12 weeks (Zhao et al., 2009).

Doujiang is fermented by naturally occurring or cultivated microorganisms (Kim, Lee, et al., 2010), including Bacillus amyloliquefaciens, Bacillus megaterium, Lactobacillus fermentum and Lactobacillus plantarum, and yeasts such as Candida humilis, Kluyveromyces lactis, Williopsis saturnus and Z. rouxii. In industry the natural fermentation can be simulated by using a mixed starter of $Z$. rouxii and L. plantarum; these starter cultures obviously do not fully represent the microbial community in the traditional production (Zhao et al., 2009).

Japanese- and Chinese-fermented soya bean pastes differ by their dominant microbiota. Whereas As. oryzae and Z. rouxii are major fungi present in most of the Chinese and Japanese fermented soybean pastes (Kim, Lee, et al., 2010), the bacterial microbiota of Japanese paste contain T. halophilus and Staphylococcus gallinarum but the Chinese paste is dominated by Bacillus spp.

\subsubsection{Doenjang}

Doenjang is a soya bean paste originating in Korea. A starter called meju is obtained by SSF with Bacillus subtilis and As. oryzae for $1-2$ months at $20-30^{\circ} \mathrm{C}$ (Kim, Hong, Song, Shin, \& Kim, 2010; Kim et al., 2009). Whereas this may suggest a pure-culture fermentation, the actual microflora is quite complex (Kim et al., 2009; Nam, Lee, \& Lim, et al., 2012) and differs between traditional and industrial doenjang. This meju 
undergoes a submerged maturation in brine with $20-25 \%$ salt content. At this salinity, microbial activity will be low but the enzymes formed in meju will be able to degrade the meju mass. After several months, a liquid stands on top of a sediment. The latter is mixed again with cooked rice and a small amount of meju and mixed. This mixture is ripened in jars for a few weeks. It may be safely assumed that part of the rice will be assimilated by the microorganisms from meju, and that the meju residue will contribute protein fractions to form the umami taste (Rhyu \& Kim, 2011) of the paste.

\subsubsection{Solid fermented soya foods}

\subsubsection{Natto and kinema}

Natto and kinema are discussed in combination because they are made by similar processes (Sarkar, Tamang, Cook, \& Owens, 1994; Wei \& Chang, 2004). Figure 18.3 outlines the essential steps in making natto and kinema. We can distinguish four phases: preparation, inoculation, incubation and finishing. The preparation for natto involves soaking whole soya beans at $21-23^{\circ} \mathrm{C}$ for $20 \mathrm{~h}$, draining, steaming at $121^{\circ} \mathrm{C}$ for 40 min and cooling to about $50^{\circ} \mathrm{C}$ for inoculation (Wei \& Chang, 2004). For kinema, whole raw soya beans are soaked in water overnight at an ambient temperature of about $25^{\circ} \mathrm{C}$, and then cooked until easily crushed (Sarkar et al., 1994) and pounded to coarse particles while hot.

The inoculation of natto is done with a pure culture of spores of $B$. subtilis natto that will germinate very well at $50^{\circ} \mathrm{C}$. For kinema, no microbial starter is added, as this is a natural fermentation allowing bacterial spores that survived the cooking process to germinate. This can be stimulated by sprinkling some wood-ash on the pounded soya beans.

In both types of fermentations, the beans are covered and kept at temperatures around $50^{\circ} \mathrm{C}$ for $1-3$ days. During this incubation period, bacilli multiply to about $10^{9}-10^{10}$ colony-forming units ( $\left.\mathrm{cfu}\right)$ per gram. In the natto process, the fermentation takes place in the packaging tray that will be sold off the supermarket shelves. Kinema is brought to the market in bulk, where it is measured out according to customer's demand and packed in plant leaves.

Microbiota predominating the kinema fermentation were studied. The functional microorganisms are Bacillus species, B. subtilis, Bacillus licheniformis, Bacillus cereus, Bacillus circulans, Bacillus thuringiensis and Bacillus sphaericus (Sarkar, Hasenack, $\&$ Nout, 2002). In addition, some bacteria are found frequently that have their origin in post-contamination after cooking. These include Enterococcus faecium and yeasts such as Candida parapsilosis and Geotrichum candidum (Sarkar et al., 1994).

\subsubsection{Tempe}

Tempe (in literature also spelled as "tempeh") is a sliceable, cake-like product made of dehulled cooked soya beans, penetrated and fermented by a mixed microbiota dominated by filamentous fungi (Nout \& Kiers, 2005). Tempe is used as a side dish with rice as a staple. It can be prepared in many ways (Shurtleff \& Aoyagi, 2001b). 


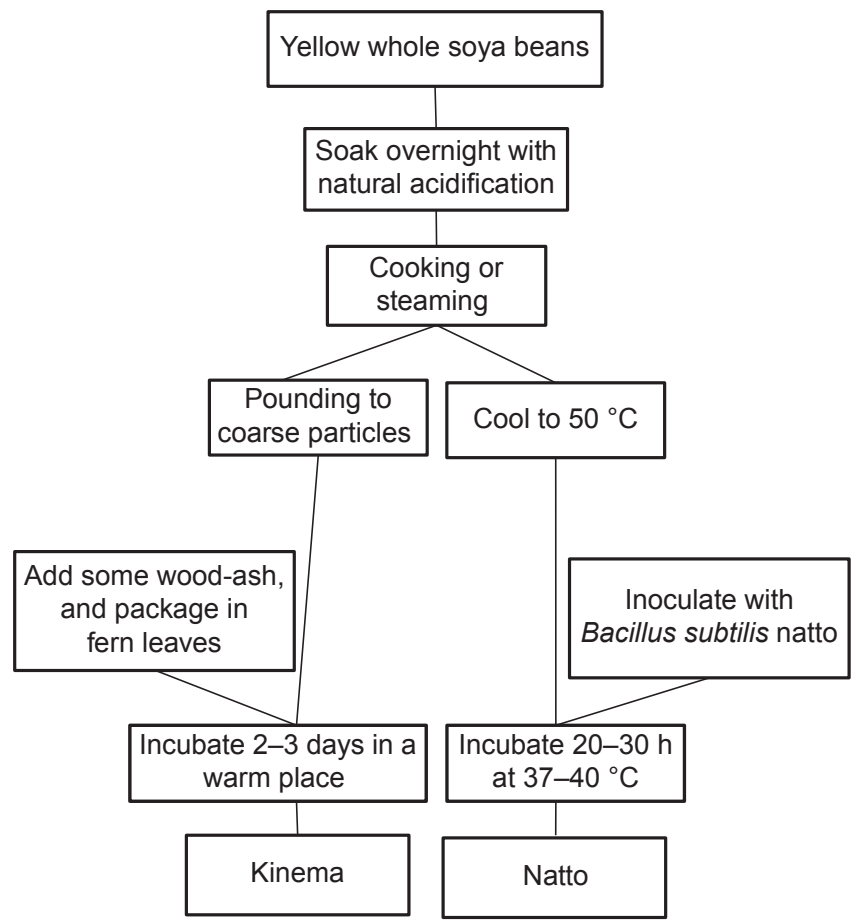

Figure 18.3 Natto and kinema processes. Natto and kinema processes are similar in principle, with the difference that natto is obtained with a pure-culture fermentation whereas kinema undergoes a natural fermentation with a mixed microflora.

Figure 18.4 shows the principles of the tempe-making process. Whole raw soya beans are soaked in water overnight at an ambient temperature of $28^{\circ} \mathrm{C}$, after which they are dehulled. The dehulled split beans (cotyledons) are cooked in water for 30-40 min, after which the cooked water is drained and the cotyledons are spread out to cool. During the cooling, the adhering water evaporates, enhancing the cooling and drying the cotyledons surface. At about $30^{\circ} \mathrm{C}$ the cotyledons are inoculated with $10^{6}$ propagules per gram of sporangiospores of filamentous fungi, mostly Rhizopus microsporus (Rombouts \& Nout, 1989; Thanh \& Nout, 2004). These can be added as pure culture, but in many small-scale production units a traditional starter called "usar" is used. Usar contains a mixed microbiota of filamentous fungi and other microrganisms (Nout, Martoyuwono, Bonné, \& Odamtten, 1992). The incubation takes place in packages that offer limited access to atmospheric oxygen (De Reu, Rombouts, \& Nout, 1995; Han \& Nout, 2000), at $30-40^{\circ} \mathrm{C}$ during $1-2$ days (the higher the temperature, the shorter the incubation) until the fungal mycelium is dense and binds the cotyledons firmly together into a solid mass. The fresh tempe is cut and sold fresh in Indonesia. In other parts of the world, the fermentation takes place in perforated packages corresponding to the weight or size units for the consumer market (Ko \& Hesseltine, 1979; Nout \& Rombouts, 1990). During the fermentation, fungal metabolism causes changes 


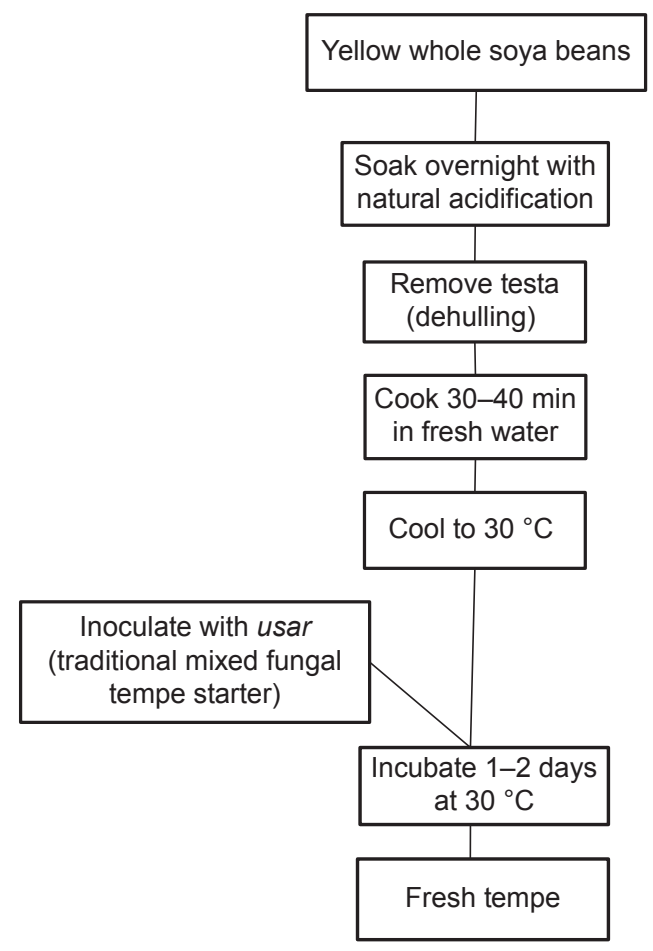

Figure 18.4 Tempe process. Tempe is made in two fermentation stages. The first stage is a natural acidification taking place during overnight soaking. The second stage is a mixed fungal-bacterial solid-state fermentation of the cooked soya beans.

in the composition of tempe, as shown in Table 18.4. Due to protein degradation, water-soluble nitrogenous substances (peptides, amino acids) are increased. Likewise, the lipid degradation results in decreased crude lipid and concomitant increase of free fatty acids. Such enzymic degradations generally result in increased amounts of lowmolecular-mass water-soluble solids. The softening of the soya beans in tempe (De Reu, Linssen, Rombouts, \& Nout, 1997) is in accordance with decreased hemicellulose levels. On the other hand, dietary fibre levels are increased due to the formation of fungal mycelial polysaccharides including cellulose and chitin.

\subsubsection{Sufu and tofu}

Sufu is a product from China, but is hardly ever known by that name (Han, Rombouts, \& Nout, 2001). The Chinese call it "Fu-ru". The appellation "sufu" was used in the 1960s in international scientific literature and since then this name has persisted. We will therefore continue the tradition.

Sufu could be described as fungal fermented and matured tofu. Sufu is a popular breakfast ingredient in China. It gives flavour and taste to the bland soya milk, vegetables and fried dough of breakfast. The process could be divided in stages: preparing 


\section{Table 18.4 Some chemical modifications during soya bean tempe fermentation}

\begin{tabular}{|l|l|l|}
\hline & $\begin{array}{l}\text { Cooked beans before } \\
\text { fermentation }(\mathbf{g} / \mathbf{1 0 0} \mathbf{g})^{*}\end{array}$ & $\begin{array}{l}\text { Tempe fermented for } \\
\mathbf{4 8 h} \mathbf{( g / 1 0 0 ~ g ) *}\end{array}$ \\
\hline Water-soluble nitrogen & 0.5 & 2.0 \\
Crude lipids & 22.5 & 14.1 \\
Free fatty acids & 0.5 & 21 \\
Hemicellulose & 2.0 & 1.1 \\
Fibre & 3.7 & $5.8^{\dagger}$ \\
Water-soluble solids & 13 & 21 \\
\hline
\end{tabular}

\footnotetext{
*Dry weight basis.

†Fibre content increases during fermentation due to the formation of fungal mycelium. Source: From Ko and Hesseltine (1979).
}

tofu, preparing pehtze, brining of pehtze, mixing with several ingredients and maturing (Han, Rombouts, et al., 2001).

Tofu is a protein-rich coagulate made from soya milk. The coagulation is done by addition of salts such as $\mathrm{Ca}_{2} \mathrm{SO}_{4}$ (gypsum) to soya milk, and the coagulate is collected and pressed to obtain a firm consistency. Slabs of tofu are cut to cubes (dices), which are inoculated by spraying them with a conidiospore suspension of the mucoraceous fungus Actinomucor repens. The dices are placed on needles so that all sides are exposed to the air, and incubated at $15-20^{\circ} \mathrm{C}$ for $5-15$ days (Han, Rombouts, et al., 2001). The resulting product is called pehtze. In principle, pehtze could be compared with koji, because it contains a range of fungal enzymes of Ac. repens that can modify the product during a later stage. Pehtze is salted with solid salt or brine to add preservation and to enhance enzyme activity. The cubes of brined pehtze are transferred to glass jars, which are topped up with maturation mix containing spices, red kojic rice (a biocolorant), sometimes rice wine and other ingredients. In the jars, the product will gradually mature: its composition will equilibrate; protein, lipid and carbohydrate fractions will be modified (Han, Ma, Rombouts, \& Nout, 2003; Han, Rombouts, \& Nout, 2004) to result in a product with a strong pungent smell and a delicious flavour.

\subsubsection{Douchi}

Douchi is a solid fermented soya bean product, consisting of individual black beans. These are used in soups, sauces, etc., as a savoury ingredient. Several types of douchi can be distinguished according to the microorganisms dominating the fermentation, i.e. bacteria or filamentous fungi. The principle of the douchi manufacturing process is shown in Figure 18.5. Soya beans are washed, soaked 3-4h, steamed for about $50 \mathrm{~min}$ and cooled to $30^{\circ} \mathrm{C}$. The beans are inoculated with Aspergillus egypticus (Zhang, Tatsumi, Fan, \& Li, 2007) and kept at $30^{\circ} \mathrm{C}$ for 3-4 days to form koji (called "qu" in Chinese). The koji is then washed with water and mixed with $16 \%$ salt, $10 \%$ water, ginger and various mixed powdered spices, and stored in closed jars for several weeks at $35^{\circ} \mathrm{C}$. Although this process seems similar to miso making, douchi is not mashed (the product consists of whole beans) and its moisture content is lower than in Miso. 


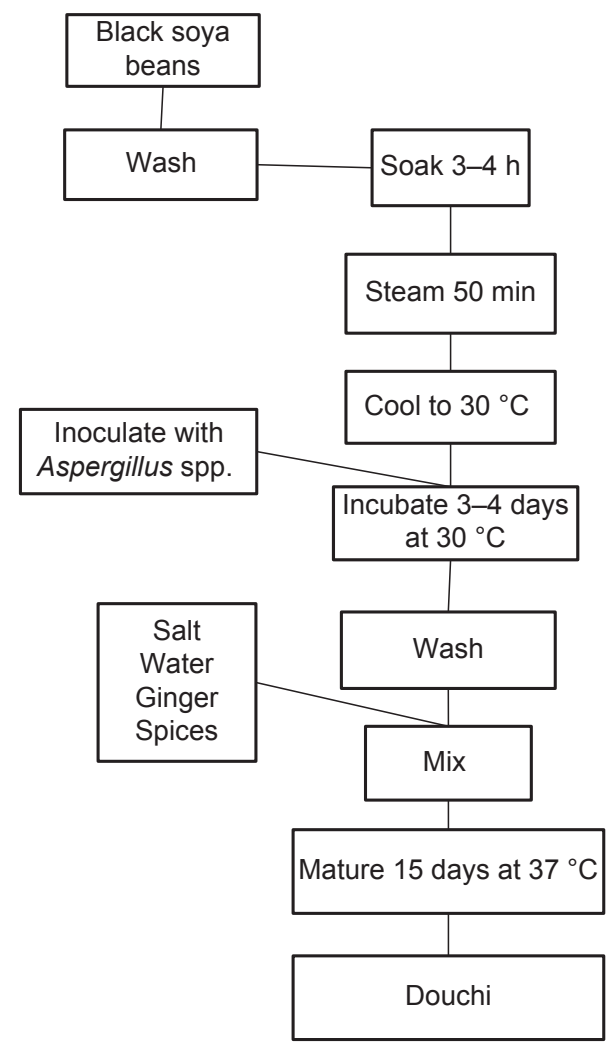

Figure 18.5 Douchi process. Black soya beans are washed, soaked, steamed and inoculated with Aspergillus spp. after cooling. The beans undergo solid-state fermentation and are then washed and matured in a mixture of brine and spices.

The chemical composition of douchi is summarized in Table 18.5. During koji formation, crude lipid and reducing sugars decrease and acidity is doubled. During maturation, fungal enzymic activities (neutral protease and $\beta$-glucosidase) caused increased amino nitrogen and organic acid levels, and degradation of isoflavones (Zhang et al., 2007).

\subsection{Quality and food safety aspects}

\subsubsection{Ecology of microbiota}

Soya fermentation processes have a strong impact on the evolution of microbes in the product. This may be positive in the case of natural fermentations, but sometimes it may constitute a hazard. Knowledge of the parameters and microorganisms involved is useful in controlling optimum quality and consumer safety. Environmental factors (Nout, De Dreu, Zuurbier, \& Bonants-Van Laarhoven, 1987) that impact 


\section{Table 18.5 Douchi: chemical modifications during the fermentation of koji and the maturation of douchi}

\begin{tabular}{|l|l|l|l|}
\hline \multirow{2}{*}{} & \multicolumn{2}{|c|}{ Koji (Qu) } & \multirow{2}{*}{ Douchi } \\
\cline { 2 - 3 } & $\mathbf{0 h}$ & $\mathbf{9 6 h}$ & \\
\hline Crude protein (\%) & 36.0 & 39.6 & \\
Crude fat (\%) & 23.8 & 19.9 & \\
Reducing sugars (mg/g) & 11.0 & 5.4 & \multirow{2}{*}{} \\
Total acids (mg/g) & 0.65 & 1.30 & 27.2 \\
Amino nitrogen (\%) & 0.15 & 0.40 & \\
Organic acids (acetic, lactic, & 1.5 & 4.3 & \\
L-pyroglutamic) (mg/g) & & & \\
\hline
\end{tabular}

Source: Data from Zhang et al. (2007).

microbiological events are (1) soaking in water overnight at ambient temperature, (2) cooking, (3) brining or salting and (4) use of defined or natural mixed starter cultures.

1. Soaking causes a diffusion of low-molecular-mass molecules such as saccharides and soluble proteins into the soaking water. Under (sub)tropical conditions, these offer ideal conditions for the growth of bacteria, first rapid-growing Enterobacteriaceae, followed by slower-growing lactic acid bacteria (LAB) that will acidify the water and the soya beans (Yan, Wolkers-Rooijackers, Nout, \& Han, 2013). This situation of natural fermentative acidification has been shown to be favourable for safety as it will prevent the establishment of spoilage and pathogenic bacteria. In colder climates where a natural acidification is consequently too slow, acidification could be enhanced by "back-slopping" (Nout, De Dreu, et al., 1987), i.e. addition of some fermented soakwater from a previous batch, containing a natural enrichment of active LAB (Yan et al., 2013).

2. Cooking at $100^{\circ} \mathrm{C}$ for 20 min or longer will kill all vegetative microbial cells, but not bacterial endospores. On the other hand, if pressure cooking is applied at $121^{\circ} \mathrm{C}$ for $20 \mathrm{~min}$, most bacterial endospores will be killed as well. In both cases the cooked product will be susceptible to bacterial overgrowth if not protected by hermetic packaging, or by inoculating it with a sufficient concentration of starter microorganisms to out-compete unwanted overgrowth. If soya beans have been acidified prior to cooking, an additional "hurdle" (low pH) helps to prevent or delay overgrowth by acid-sensitive spoilage bacteria. During a cooking step at $100^{\circ} \mathrm{C}$, bacterial endospores will be activated to germinate as soon as the cooked beans have cooled down to about $50^{\circ} \mathrm{C}$, enabling them to grow rapidly and colonize the cooked beans (Nout, De Dreu, et al., 1987).

3. Brining or salting increases the $\mathrm{NaCl}$ concentration to levels that are inhibitory to most microorganisms (Han, Sesenna, Beumer, \& Nout, 2005). Only halotolerant or halophilic bacteria or yeasts would have the opportunity to (slowly) grow and cause effects.

4. The type of starters used can vary from defined single-strain starters to traditional mixed starters. Defined single or mixed starters, such as used for natto and sufu, have been selected for their specific properties, and in order to draw appropriate profit from their addition, they need to be provided with optimum conditions for growth including absence of competing microbiota and the control of temperature, $\mathrm{pH}$ and water activity. Natural mixed microbiota 
are cheaper; they have adapted to the prevailing environment and substrate and are therefore robust, but their composition and their performance are not predictable.

\subsubsection{Fungal functions and hazards}

The range of functional fungi is rather limited. Of the filamentous fungi, the family Mucoraceae is important because it contains genera such as Mucor, Rhizopus and Actinomucor, which are all involved in soya fermentations (Han, Kuijpers, Thanh, $\&$ Nout, 2004). The function of these moulds is to provide texture and formation of hydrolytic enzymes. Several species of Rhizopus, namely Rhizopus oryzae, Rhizopus rhizopodiformis, R. microsporus, Rhizopus oligosporus and Rhizopus homothallicus, were categorized as potentially pathogenic because of their ability to grow at $37^{\circ} \mathrm{C}$ (Scholer \& Müller, 1971). Therefore at industrial level, precautions should be taken to avoid inhalation of sporangiospores. This group of fungi is not known to produce mycotoxins; the mycotoxin "rhizonin" that was reported previously is not a fungal metabolite but it is produced by bacterial endosymbionts, such as Burkholderia sp. (Partida Martinez et al., 2007).

Of the Fungi Imperfecti, the genus Aspergillus plays an important role in soya koji. It was established that the most frequently used species As. oryzae does not produce mycotoxins and is safe for human consumption (Barbesgaard, Heldthansen, \& Diderichsen, 1992). However, the fact that this fungus belongs to the same section (Aspergillus Flavi section) as Apergillus flavus and Apergillus parasiticus, both potent producers of aflatoxins, has caused much research into the safety of fungal strains. It was demonstrated that genotypes of As. oryzae used in koji making were not diverse, and had a considerably smaller genome than As. flavus (Wicklow, McAlpin, \& Yeoh, 2007).

Of the Ascomycetes, the genus Monascus is important in the production of red kojic rice, also called "angkak". This product is used as a biocolourant for sufu, and more recently it is used as a health food-supplement. Monascus spp. are able to produce the mildly carcinogenic mycotoxin citrinin (Lee, Lee, \& Pan, 2010; Mornar, Sertić, \& Nigović, 2013). Monascus-fermented commercial soya products in Korea and China were analyzed for their citrinin content. In China (Liu, Wu, Su, Chung, \& $\mathrm{Yu}, 2005)$, the cytotoxicity of the fermented products was considered a hazard requiring control, whereas in Korea (Kim, Ji, \& Lee, 2007), most tested products had citrinin levels below the allowed level of $50 \mu \mathrm{g} / \mathrm{kg}$. Selection of starter strains that produce only low levels of citrinin has been reported (Pattanagul, Pinthong, Phianmongkhol, \& Tharatha, 2008), and their use would contribute to food safety.

Yeasts occur in fermented soya foods, but have not been reported in connection with hazardous situations.

\subsubsection{Bacterial functions and hazards}

Several genera of bacteria have positive effects on the quality of fermented soya foods. Lactic acid bacteria (LAB) are important for flavour as well as for protection against pathogenic contaminants. The acidification by LAB was shown to inhibit the growth 
of B. cereus in tempe (Nout, Beernink, \& Bonants-Van Laarhoven, 1987), whereas their potential to form bacteriocins may contribute to the protection against Listeria sp. Klebsiella spp. are found in, for example, kinema and soya soak water. This genus is known for its ability to produce vitamin $\mathrm{B}_{12}$. The occurrence of Bacillus spp. in various products such as natto, kinema and douchi was mentioned. This genus is a strong producer of hydrolytic enzymes that enable digestibility of fermented soya foods. It was also shown to produce nattokinase, which may protect against thrombosis (Wang et al., 2006).

However, the occurrence of contaminations by B. cereus in fermented products dominated by $B$. subtilis could be a matter of concern. The ability of B. cereus to form toxins was evaluated in kinema, which is normally dominated by $B$. subtilis. It was demonstrated that $B$. cereus can produce hazardous levels of toxins when proliferating as a pure culture on soya beans. However, in the presence of a competing dominance of B. subtilis, such as in kinema, only insignificant amounts of toxin were formed (Nout, Bakshi, \& Sarkar, 1998). In tempe, protein-degradation fractions inhibited the germination of B. cereus endospores (Roubos-van den Hil, Dalmas, Nout, \& Abee, 2010).

A similar phenomenon was observed in sufu, contaminated on purpose with enterotoxin-producing Staphylococcus aureus. Although S. aureus was able to grow in the high salinity of sufu, it was not able to form its enterotoxins (Han et al., 2005).

Concluding, it may appear that under fermentation conditions dominated by strongly competing fermentation microorganisms, toxin-producing bacteria have only limited possibilities to produce their toxins. Nevertheless, fermented soya foods require control for chemical and microbiological safety (Han, Beumer, Rombouts, \& Nout, 2001), based on Hazard Analysis Critical Control Points (HACCP) concepts, because post-processing contaminations with Salmonella, Listeria and other pathogens can occur at later stages in the food production chain.

\subsection{Biofunctionality and health aspects}

\subsubsection{Digestibility}

The digestibility of soya is limited because of the presence of some anti-nutritional factors such as trypsin inhibitors, lectins and flatulence-causing oligosaccharides, and because of structural barriers (cell walls) that are poorly digestible and that inhibit diffusion of digestive enzymes.

Fermentation processes have been shown to enhance digestibility significantly (Kiers, Nout, \& Rombouts, 2000; Kiers, Van Laeken, Rombouts, \& Nout, 2000). As an example, fungal SSF of soya beans is illustrated. Digestibility can be measured in several ways. The most expensive but representative approach is an in-vivo feeding experiment (Kiers et al., 2003) monitoring weight gain and feed conversion ratio as criteria for digestibility. Such experiments are usually conducted to confirm previous laboratory-based in-vitro experiments that can be carried out under controlled conditions and that require only small quantities of samples. 
In-vitro digestibility tests (Kiers, Nout, et al., 2000) involve the use of artificial saliva, gastric and pancreatic juices during an optimized protocol of incubation periods and $\mathrm{pH}$ values; after enzymic digestion, the digest is the liquefied portion and this can be evaluated for its composition, in relation to that of the undigested starting material. Table 18.6 shows the effect of SSF on the in-vitro digestibility and accessibility of soya nutrients. This table illustrates that $22.3 \%$ of soaked and cooked soya can be digested by human digestive enzymes into water-soluble breakdown products. This is called in-vitro digestibility. The in-vitro accessibility refers to the smaller compounds that can pass a $12-14 \mathrm{kDa}$ cut-off dialysis membrane simulating the intestinal mucosa barrier. The essential information of the table is that the fermentation with $R$. microsporus causes a strong relative increase of in-vitro accessible compounds, from $4.8 \%$ to $16.4 \%$.

In-vivo tests can be done with human volunteers, but in some cases it is more convenient and statistically more significant to test with farm animals such as piglets. These can be selected for genetic homogeneity, and they can be given the same controlled diet (Kiers et al., 2003). In the context of combating porcine weaning diarrhoea, in-vivo digestibility tests were done, and weight gain and feed conversion were measured. This gives more information than in-vitro digestion tests because here the uptake and metabolism of nutrients are all included in the outcome, i.e. weight gain. Table 18.7 shows data comparing the performance of a standard animal feed containing either toasted soya, cooked soya or cooked and fermented (R. microsporus) soya. Daily weight gain, feed intake and feed conversion ratio with cooked and cooked-fermented soya did not differ significantly, but both were significantly better than toasted soya. Cooked-fermented soya gave a significant mitigation of Escherichia coliinduced diarrhoea (Kiers et al., 2003).

\subsubsection{Formation and bioaccessibility of functional molecules}

Due to the activity of the functional fermentation microbiota, molecules can be formed in fermented soya foods that have been proven and/or suggested to have positive influences on human health. Folic acid or folate, and vitamin $\mathrm{B}_{12}$ or cyanocobalamin are vitamins that can be synthesized by microorganisms (Mo et al., 2013). Isoflavones in soya are glycosides and as such, poorly accessible. By enzymic action these

\section{Table 18.6 Effect of solid-state fermentation of cooked soya beans on in-vitro digestibility and accessibility}

\begin{tabular}{|l|l|l|}
\hline & Digestibility (\%) & Accessibility (\%) \\
\hline $\begin{array}{l}\text { Soaked and cooked soya beans } \\
\text { Soaked, cooked and fermented with } \\
\text { Rhizopus microsporus LU582, 24h } \\
\text { at } 30^{\circ} \mathrm{C}\end{array}$ & 22.3 & 4.8 \\
\hline
\end{tabular}

Accessibility was estimated as soluble solids passing through a $12-14 \mathrm{kDa}$ cut-off dialysis membrane. Source: Data from Kiers, Nout, et al. (2000). 
Table 18.7 In-vivo weight gain, feed intake, feed conversion and severity of Escherichia coli-induced diarrhoea in piglets fed on animal formula containing iso-energetic levels of toasted, cooked or cooked and solid-state fermented soya

\begin{tabular}{|c|c|c|c|}
\hline & Toasted & Cooked & $\begin{array}{l}\text { Cooked and SSF } \\
\text { with Rhizopus } \\
\text { microsporus LU573 } \\
\text { for } 48 \mathrm{~h} \text { at } 37^{\circ} \mathrm{C}\end{array}$ \\
\hline $\begin{array}{l}\text { Average daily weight gain } \\
\text { (g) }\end{array}$ & $334 \pm 14^{\mathrm{a}}$ & $376 \pm 14^{b}$ & $393 \pm 15^{b}$ \\
\hline $\begin{array}{l}\text { Average daily feed intake } \\
\text { (g) }\end{array}$ & $463 \pm 17^{a}$ & $501 \pm 18^{b}$ & $523 \pm 19^{b}$ \\
\hline $\begin{array}{l}\text { Feed conversion (intake: } \\
\text { weight gain ratio) }\end{array}$ & $0.72 \pm 0.01^{\mathrm{a}}$ & $0.75 \pm 0.01^{b}$ & $0.74 \pm 0.01^{b}$ \\
\hline Average diarrhoea severity & $2.3 \pm 1.1^{\mathrm{a}}$ & $1.8 \pm 0.8^{\mathrm{a}, \mathrm{b}}$ & $1.7 \pm 0.6^{\mathrm{b}}$ \\
\hline
\end{tabular}

a,bValues with different superscript letters differ significantly $(p<0.10)$.

24 piglets per treatment: diarrhoea severity: $0=$ firm and formed faeces, $2=$ shapeless faeces, $4=$ liquid faeces and 6 = watery diarrhoea. SSF, solid-state fermentation.

Source: Data from Kiers et al. (2003).

glycosides could be hydrolyzed into saccharides and isoflavone aglycons (Champagne, Tompkins, Buckley, \& Green-Johnson, 2010), the latter being easier to be taken up in the human intestinal tract.

\subsubsection{Folate and vitamin $B_{12}$}

Table 18.8 shows folate and vitamin $B_{12}$ in fermented soya (Mo et al., 2013). Folate and vitamin $\mathrm{B}_{12}$ are vitamins formed by microorganisms. Whereas folate also occurs naturally in soya beans, soya does not contain vitamin $B_{12}$ naturally. During soaking and cooking, some of the natural folate from soya beans is lost in soaking and cooking water. However, these losses are easily compensated by the synthesis of folate by fungal fermentation. The table shows that the level of folate produced differs with the fungal starter culture used, but is not strongly affected by cooking of the tempe. For vitamin $\mathrm{B}_{12}$, the levels depend on bacteria present during the fermentation. Some authors were able to obtain high vitamin $\mathrm{B}_{12}$ levels by using selected starter cultures in tempe fermentation (Okada, 1989). Cooking of tempe lowers the vitamin $B_{12}$ level.

\subsubsection{Isoflavones and aglycons}

Table 18.9 shows the formation of the isoflavone aglycons daidzein and genistein during the soaking, cooking and fungal fermentation of soya beans (Mo et al., 2013). These aglycons are formed by degradation of the corresponding glycosides daidzin and genistin. Whereas the glycosides are not bio-accessible, the aglycons show a very high (about 100\%) accessibility. Isoflavones have been associated with reduced 


\section{Table 18.8 Folate and vitamin $B_{12}$ in raw, soaked, cooked and fermented soya $(\mu \mathrm{g} / \mathrm{kg}$ dry matter)}

\begin{tabular}{|l|l|l|}
\hline & Folate & Vitamin $\mathbf{B}_{\mathbf{1 2}}$ \\
\hline Raw soya beans & 2671 & ND \\
Soaked with biological acidification, $24 \mathrm{~h}$ at $30^{\circ} \mathrm{C}^{*}$ & 1915 & ND \\
Cooked beans, 20 min at $100^{\circ} \mathrm{C}$ & 1340 & ND \\
Fermented with Rhizopus microsporus at $30^{\circ} \mathrm{C}$ & 1889 & 0.86 \\
$\quad$ for $24 \mathrm{~h}$ & & \\
Fermented with $R$. microsporus at $30^{\circ} \mathrm{C}$ for $48 \mathrm{~h}$ & 3904 & 0.85 \\
Cooked fermented product & 3153 & 0.34 \\
Fermented with traditional mixed tempe starter at & 1577 & 0.63 \\
$30^{\circ} \mathrm{C}$ for $24 \mathrm{~h}$ & & \\
Fermented with traditional mixed tempe starter at & 1625 & 1.06 \\
$30^{\circ} \mathrm{C}$ for $48 \mathrm{~h}$ & & \\
Cooked fermented product & 1619 & 0.72 \\
\hline
\end{tabular}

ND, not determined.

*Soaked water was inoculated with Lactobacillus plantarum LU852, $10^{6} \mathrm{cfu} / \mathrm{ml}$ water.

Source: Data from Mo et al. (2013).

\section{Table 18.9 Formation of isoflavone aglycons daidzein and genistein in SSF soya (mg/kg dry matter)}

\begin{tabular}{|l|l|l|}
\hline & Daidzein & Genistein \\
\hline Raw soya beans & 56 & 69 \\
Soaked with natural fermentation $24 \mathrm{~h}$ at $30^{\circ} \mathrm{C}$ & 406 & 397 \\
Cooked beans, 20 min at $100^{\circ} \mathrm{C}$ & 562 & 678 \\
Fermented with Rhizopus microsporus at $30^{\circ} \mathrm{C}$ & 684 & 863 \\
$\quad$ for $48 \mathrm{~h}$ & & 1388 \\
Cooked fermented product & 1391 & \\
\hline
\end{tabular}

SSF, solid-state fermentation. Aglycons (daidzein, genistein) were $100 \%$ accessible in vitro. Source: Data from Mo et al. (2013).

prevalence of breast and prostate cancer, cardiovascular diseases and osteoporosis (Mo et al., 2013). The data show that the formation of aglycons starts already during the soaking, resulting from the activity of endogenous glucosidases of raw soya beans. During early warming stages of cooking, these enzymes continue their action. In cooked beans, fungi will continue to form glucosidases, which will liberate aglycons during the incubation stage and during the cooking of tempe.

\subsubsection{Obesity control}

Some products such as doenjang have been associated with weight loss in obese persons (Cha et al., 2012). A study demonstrated that daily supplementation of $9.9 \mathrm{~g}$ dry doenjang/day for 12 weeks reduced body weight and visceral fat in overweight adults. 
Although the study did not aim to elucidate the mechanism of action, it was suggested that isoflavone aglycons are associated with the expression of human lipid metabolism genes.

\subsubsection{Anti-diarrhoea effect of tempe and tofu}

Diarrhoea can have many causes. One type affecting young humans and animals is called "infant weaning diarrhoea", and it involves babies and piglets that have to switch from mother's milk to solid food. This is a stressful event because the intestinal epithelium and mucosa have to adapt to different chemical composition of its content. Due to stress, the infant has a higher susceptibility to intestinal infections with pathogens such as rotavirus and bacteria such as E. coli. Such pathogens, singly or combined, can disturb the mineral and fluid balances of the infant and lead to rapid dehydration and interrupted growth. In human babies, weaning diarrhoea is one of the causes of "under-five mortality", whereas in piglets it causes economic losses due to delayed growth performance.

Traditionally it had been observed in Indonesia that tempe given during infant diarrhoea can reduce its severity and shorten its duration (Karyadi \& Lukito, 1996; Mahmud, Hermana, \& Karyadi, 1985; Soenarto, Sudigbia, Hermana, Karmini, \& Karyadi, 1997). This prompted a systematic study of the anti-diarrhoea effect of fermented soya, and the mechanism of this effect (Roubos-van den Hil, Nout, Beumer, van der Meulen, \& Zwietering, 2009).

First, in-vitro approaches were used to determine the effect of the soya fermentation by various microorganisms such as LAB, Bacillus spp. and filamentous fungi on the digestibility of soya beans. It became clear that LAB do not have a significant impact on digestion, but that Bacillus spp. and filamentous fungi cause a considerable increase in the generation of water-soluble low-molecular mass molecules in the digest (Kiers, Nout, \& Rombouts, 2000).

Such artificial digests were investigated further in-vivo in piglets, at the small intestine level (Kiers et al., 2006). Digests were perfused in segments of the small intestine of anaesthetized piglets. Studies were made of the effect of such digests on the nutrient uptake and fluid balance under controlled healthy conditions, and were compared with situations of stress that induced diarrhoea. Such stresses were induced by previous exposure to diarrhoea-causing $E$. coli and rotavirus, singly or combined.

In particular, digests of tempe caused a significant protection against fluid loss (read: diarrhoea), and this was confirmed in a larger-scale piglet feeding trial under controlled conditions during which the piglets were not intentionally stressed by exposure to diarrhoea-causing pathogens. Tempe-fed piglets had better weight gain and feed conversion, and were less affected by weaning diarrhoea (Kiers et al., 2003).

Subsequent investigations aimed at elucidating the mechanism of this protective effect and finding the molecules responsible. This was approached by a series of chemical separations and extractions, to detect which class of compounds (proteins, enzymes, carbohydrates, etc.) were the most effective protectants. In order to measure and compare small samples in a laboratory setting, cell-line experiments were developed. 
Since the hypothesis was that diarrhoea is caused by $E$. coli and that attachment of $E$. coli cells to intestinal epithelial cells is a first requirement for its pathogenesis, the attachment or adhesion was considered a crucial target. The anti-adhesion effect of tempe fractions was tested in piglet cells (Kiers, Nout, Rombouts, Nabuurs, \& Van der Meulen, 2002) and in human cell lines (Caco-2) (Roubos-van den Hil et al., 2009). Both experimental approaches were used and eventually led to the finding that the most effective protectants are carbohydrate fractions (Kiers, Nout, Rombouts, Nabuurs, \& van der Meulen, 2007) of a molecular mass $>30$ kDa (Roubos-Van Den Hil, Schols, Nout, Zwietering, \& Gruppen, 2010), which are not present in cooked soya beans but are gradually formed by fungal enzyme activity. The chemical composition of this carbohydrate (oligosaccharide) fraction revealed a relative dominance of arabinose (Roubos-Van Den Hil, Schols, et al., 2010), which indicates that their origin must be in the arabinan or arabinogalactan side chain of the pectic cell-wall polysaccharides of the soya beans.

Whereas previously described experiments had all been focused on tempe, we discovered later that tofu (Mo, Zhu, \& Nout, 2012) has an anti-adhesive effect as well, which is of much interest because the world consumption of tofu is many times larger than that of tempe.

\subsubsection{Salt reduction}

Public health authorities worldwide are concerned about the relation between salt consumption, particularly sodium, and diseases such as hypertension. There is a need to avoid excessive salt intake, and in this context, food-producing enterprises are urged by international (WHO, 2012) and national health and consumer organizations (Dötsch et al., 2009) to reduce sodium chloride in their products. This is not an easy task, because salt is a functional ingredient in many foods. It is connected with consumer acceptance (taste), texture (through its interaction with, for example, proteins) and shelf-life (salt reduces the water activity and has its specific antimicrobial effect). Nevertheless, it is appropriate to experiment with decreasing levels of added $\mathrm{NaCl}$ in product formulations. Another option is to replace some of the $\mathrm{NaCl}$ by other salts such as $\mathrm{KCl},\left(\mathrm{NH}_{4}\right) \mathrm{Cl}, \mathrm{CaCl}_{2}$, etc. Each of these has its own specific properties, such as different taste, hygroscopicity, and effect on water activity. Whereas several food-producing enterprises are actively pursuing sodium reduction or substitution, there is still much scope for further implementation and control.

In view of fermented soya bean products, and referring to Table 18.1, many candidates for salt reduction are certainly present. Some industrial products have been modified already at an experimental scale, such as soya sauce (Yanfang, 2010) and douchi (Gao \& Liu, 2010).

In the context of sufu manufacture, the functionality of salt was investigated. The amount of sodium chloride added to pehtze for further maturation could be successfully reduced from $11 \%$ (control) to $8 \%$ (Han, Cao, Rombouts, \& Nout, 2004). This resulted in a faster modification of protein fractions (Han, Wang, Rombouts, \& Nout, 2003), so this may bring an advantage of the final product being available earlier for the consumer. At lower $\mathrm{NaCl}$ concentrations (5\%), however, it was noticed that the 
preservative effect of salt was lost, as evidenced by product spoilage caused by acidifying bacteria (Han, Cao, et al., 2004).

Nowadays food producers do not need to rely anymore on preservation by salt alone. Combinations of reduced salt with other preservative "hurdles" such as acidity, bacteriocins, mild pasteurization, modified atmosphere packaging and high hydrostatic pressure are certainly worth trying.

\subsection{Future trends and research needs}

With the rapid development of the digital age and of molecular biology, sophisticated methods of microbiological and chemical analysis gradually become affordable, enabling their use on a routine basis for monitoring and control purposes. This is of obvious importance in the continuous battle against food frauds, and to assure food safety. It is also a stimulus for research and development, as it allows the construction of a knowledge base of complex microbiota and their ecology in fermented soya foods.

Based on detailed knowledge and understanding of the robustness of microbial consortia, an even better definition can be drawn of the required properties of starters for specific fermentations. Such a "starter signature" could include its genome, metabolome, transcriptome and other novel "omes".

Another topic of future attention will certainly be the "functionality" of microorganisms and chemical substances in terms of public health and product quality in general. Apart from the issue of whether authorities treat medical claims in a different way from health food claims, it is essential in all cases that perceived or expected favourable effects of microorganisms or food components are substantiated in vivo and that their mechanism of action is explained and proven.

As mentioned earlier, the reduction of sodium intake to healthy levels is an issue of world-scale. Clearly, several fermented soy foods are vehicles of sodium intake, and reduction of their salt content will benefit humans and environment alike.

Finally, fermented foods may be ancient, but they will remain popular in the future because they are part of our life and culture and, in addition, their health benefits are increasingly being recognized and appreciated. We should devote more attention towards their updating.

\subsection{Sources of further information and advice}

Several books covering food fermentation and fermented foods in general are worth mentioning for further reading. They include works of Rose (1982), Steinkraus (1989, 1996), Wood, Adams, et al. (1985), Wood, Beddows, et al. (1985), Boekhout and Robert (2003) and Adams and Nout (2001).

A review dealing with fermented foods in general by Campbell-Platt (1994) should not be missed. In addition, the functional properties of fermented foods have been 
reviewed, such as the beneficial effects of Monascus fermented foods (Lee \& Pan, 2012), pre- and probiotic effects of fermented foods (Mohammadi \& Mortazavian, 2011; Peres, Peres, Hernández-Mendoza, \& Malcata, 2012), bioactive phenols in fermented foods (Martins et al., 2011) and other functional fermented foods (Marotta et al., 2012).

Specifically on soya bean fermentations, reviews on Thua Nao (Chukeatirote, Dajanta, \& Apichartsrangkoon, 2010), the use of okara (soya milk residue) (O'Toole, 1999) and the functionality of soya oligosaccharides (Choct, Dersjant-Li, McLeish, \& Peisker, 2010) are recommended.

\section{References}

Adams, M. R., \& Nout, M. J. R. (Eds.). (2001). Fermentation and food safety. Gaithersburg, MD: Aspen Publishers.

Aidoo, K. E., Nout, M. J. R., \& Sarkar, P. K. (2006). Occurrence and function of yeasts in Asian indigenous fermented foods. FEMS Yeast Research, 6, 30-39.

American Soybean Association. (2012a). Soybeans' many edible uses. http:// wwwsoystatscom/2012/edibleuseshtm. [18-5-2013 11:08:01].

American Soybean Association. (2012b). Soybeans' many industrial uses. http:// wwwsoystatscom/2012/industrialuseshtm. [18-5-2013 11:05:22].

Barbesgaard, P., Heldthansen, H. P., \& Diderichsen, B. (1992). On the safety of Aspergillus oryzae - a review. Applied Microbiology and Biotechnology, 36, 569-572.

Boekhout, T., \& Robert, V. (Eds.). (2003). Yeasts in food: Beneficial and detrimental aspects. Hamburg: B. Behr's Verlag GmbH \& Co.KG.

Campbell-Platt, G. (1994). Fermented foods - a world perspective. Food Research International, 27, 253-257.

Cha, Y. S., Yang, J. A., Back, H. I., Kim, S. R., Kim, M. G., Jung, S. J., et al. (2012). Visceral fat and body weight are reduced in overweight adults by the supplementation of doenjang, a fermented soybean paste. Nutrition Research and Practice, 6, 520-526.

Champagne, C. P., Tompkins, T. A., Buckley, N. D., \& Green-Johnson, J. M. (2010). Effect of fermentation by pure and mixed cultures of Streptococcus thermophilus and Lactobacillus helveticus on isoflavone and B-vitamin content of a fermented soy beverage. Food Microbiology, 27, 968-972.

Chen, K. I., Erh, M. H., Su, N. W., Liu, W. H., Chou, C. C., \& Cheng, K. C. (2012). Soyfoods and soybean products: from traditional use to modern applications. Applied Microbiology and Biotechnology, 96, 9-22.

Choct, M., Dersjant-Li, Y., McLeish, J., \& Peisker, M. (2010). Soy oligosaccharides and soluble non-starch polysaccharides: a review of digestion, nutritive and anti-nutritive effects in pigs and poultry. Asian-Australasian Journal of Animal Sciences, 23, 1386-1398.

Chukeatirote, E., Dajanta, K., \& Apichartsrangkoon, A. (2010). Thua nao, indigenous Thai fermented soybean: a review. Journal of Biological Science, 10, 581-583.

De Reu, J. C., Linssen, V. A. J.M., Rombouts, F. M., \& Nout, M. J. R. (1997). Consistency, polysaccharidase activities and non-starch polysaccharides content of soya beans during tempe fermentation. Journal of the Science of Food and Agriculture, 73, 357-363.

De Reu, J. C., Rombouts, F. M., \& Nout, M. J. R. (1995). Influence of acidity and initial substrate temperature on germination of Rhizopus oligosporus sporangiospores in tempe fermentation. Journal of Applied Bacteriology, 78, 200-208. 
Dötsch, M., Busch, J., Batenburg, M., Liem, G., Tareilus, E., Müller, R., et al. (2009). Strategies to reduce sodium consumption: a food industry perspective. Critical Reviews in Food Science and Nutrition, 49, 841-851.

Fukushima, D. (1989). Industrialization of fermented soy sauce production centering around Japanese shoyu. In K. H. Steinkraus (Ed.), Industrialization of indigenous fermented foods (pp. 1-88). New York, Basel: Marcel Dekker, Inc.

Gao, Y., \& Liu, X. (2010). Subsection-fermented process of subsalt-fermented Douchi using multiple strains. Nongye Gongcheng Xuebao/Transactions of the Chinese Society of Agricultural Engineering, 26, 369-373.

Han, B.-Z., Beumer, R. R., Rombouts, F. M., \& Nout, M. J. R. (2001). Microbiological safety and quality of commercial sufu - a Chinese fermented soybean food. Food Control, 12, $541-547$.

Han, B.-Z., Kuijpers, A. F. A., Thanh, N. V., \& Nout, M. J. R. (2004). Mucoraceous moulds involved in the commercial fermentation of sufu pehtze. Antonie van Leeuwenhoek, 85, 253-257.

Han, B.-Z., Sesenna, B., Beumer, R. R., \& Nout, M. J. R. (2005). Behaviour of Staphylococcus aureus during sufu production at laboratory scale. Food Control, 16, 243-247.

Han, B. Z., Cao, C.-F., Rombouts, F. M., \& Nout, M. J. R. (2004). Microbial changes during the production of sufu - a Chinese fermented soybean food. Food Control, 15, 265-270.

Han, B. Z., Ma, Y., Rombouts, F. M., \& Nout, M. J. R. (2003). Effects of temperature and relative humidity on growth and enzyme production by Actinomucor elegans and Rhizopus oligosporus during sufu pehtze preparation. Food Chemistry, 81, 27-34.

Han, B. Z., \& Nout, M. J. R. (2000). Effects of temperature, water activity and gas atmosphere on mycelial growth of tempe fungi Rhizopus microsporus var. microsporus and $R$. microsporus var. oligosporus. World Journal of Microbiology and Biotechnology, 16, 853-858.

Han, B. Z., Rombouts, F. M., \& Nout, M. J. R. (2001). A Chinese fermented soybean food. International Journal of Food Microbiology, 65, 1-10.

Han, B. Z., Rombouts, F. M., \& Nout, M. J. R. (2004). Amino acid profiles of sufu, a Chinese fermented soybean food. Journal of Food Composition and Analysis, 17, 689-698.

Han, B. Z., Wang, J. H., Rombouts, F. M., \& Nout, M. J. R. (2003). Effect of $\mathrm{NaCl}$ on textural changes and protein and lipid degradation during the ripening stage of sufu, a Chinese fermented soybean food. Journal of the Science of Food and Agriculture, 83, 899-904.

Karyadi, D., \& Lukito, W. (1996). Beneficial effects of tempeh in disease prevention and treatment. Nutrition Reviews, 54, S94-S98.

Kiers, J. L., Meijer, J. C., Nout, M. J. R., Rombouts, F. M., Nabuurs, M. J. A., \& Van der Meulen, J. (2003). Effect of fermented soya beans on diarrhoea and feed efficiency in weaned piglets. Journal of Applied Microbiology, 95, 545-552.

Kiers, J. L., Nout, M. J. R., \& Rombouts, F. M. (2000). In vitro digestibility of processed and fermented soya bean, cowpea and maize. Journal of the Science of Food and Agriculture, $80,1325-1331$.

Kiers, J. L., Nout, M. J. R., Rombouts, F. M., Nabuurs, M. J. A., \& Van der Meulen, J. (2002). Inhibition of adhesion of enterotoxic Escherichia coli $\mathrm{K} 88$ by soya bean tempe. Letters in Applied Microbiology, 35, 311-315.

Kiers, J. L., Nout, M. J. R., Rombouts, F. M., Nabuurs, M. J. A., \& van der Meulen, J. (2007). A high molecular weight soluble fraction of tempeh protects against fluid losses in Escherichia coli-infected piglet small intestine. British Journal of Nutrition, 98, 320-325.

Kiers, J. L., Nout, M. J. R., Rombouts, F. M., Van Andel, E. E., Nabuurs, M. J. A., \& Van der Meulen, J. (2006). Effect of processed and fermented soya bean on net absorption in enterotoxigenic Escherichia coli-infected piglet small intestine. British Journal of Nutrition, 95, 1193-1198. 
Kiers, J. L., Van Laeken, A. E. A., Rombouts, F. M., \& Nout, M. J. R. (2000). In vitro digestibility of Bacillus fermented soya bean. International Journal of Food Microbiology, 60, $163-169$.

Kim, H. G., Hong, J. H., Song, C. K., Shin, H. W., \& Kim, K. O. (2010). Sensory characteristics and consumer acceptability of fermented soybean paste (Doenjang). Journal of Food Science, 75, S375-S383.

Kim, H. J., Ji, G. E., \& Lee, I. (2007). Natural occurring levels of citrinin and monacolin $\mathrm{K}$ in Korean Monascus fermentation products. Food Science and Biotechnology, 16, 142-145.

Kim, T. W., Lee, J. H., Kim, S. E., Park, M. H., Chang, H. C., \& Kim, H. Y. (2009). Analysis of microbial communities in doenjang, a Korean fermented soybean paste, using nested PCR-denaturing gradient gel electrophoresis. International Journal of Food Microbiology, $131,265-271$.

Kim, T. W., Lee, J. H., Park, M. H., \& Kim, H. Y. (2010). Analysis of bacterial and fungal communities in Japanese- and Chinese-fermented soybean pastes using nested PCR-DGGE. Current Microbiology, 60, 315-320.

Ko, S. D., \& Hesseltine, C. W. (1979). Tempe and related foods. In A. H. Rose (Ed.), Microbial biomass (pp. 115-140). London, United Kingdom: Academic Press.

Lee, B. H., \& Pan, T. M. (2012). Benefit of Monascus-fermented products for hypertension prevention: a review. Applied Microbiology and Biotechnology, 94, 1151-1161.

Lee, C. H., Lee, C. L., \& Pan, T. M. (2010). A 90-D Toxicity study of Monascus-fermented products including high citrinin level. Journal of Food Science, 75, T91-T97.

Li, H. M., \& Ma, Y. (2003). Present situation and prospect of the production of traditional bean paste. Science and Technology of Food Industry (in Chinese) (Suppl.), 202-206.

Lim, G. (1991). Indigenous fermented foods in South East Asia. ASEAN Food Journal, 6, 83-101.

Liu, B. H., Wu, T. S., Su, M. C., Chung, C. P., \& Yu, F. Y. (2005). Evaluation of citrinin occurrence and cytotoxicity in Monascus fermentation products. Journal of Agricultural and Food Chemistry, 53, 170-175.

Mahmud, M. K., Hermana, \& Karyadi, D. (1985). A preliminary study on the use of tempeh based formula in the dietary treatment of chronic diarrhea. Majalah Kedokteran Indonesia, $35,443-446$.

Marotta, F., Catanzaro, R., Yadav, H., Jain, S., Tomella, C., Polimeni, A., et al. (2012). Functional foods in genomic medicine: a review of fermented papaya preparation research progress. Acta Biomedica, 83, 21-29.

Martins, S., Mussatto, S. I., Martínez-Avila, G., Montañez-Saenz, J., Aguilar, C. N., \& Teixeira, J. A. (2011). Bioactive phenolic compounds: production and extraction by solid-state fermentation. A review. Biotechnology Advances, 29, 365-373.

Mo, H.-Z., Kariluoto, S., Piironen, V., Zhu, Y., Sanders, M. G., Vincken, J.-P., et al. (2013). Effect of soybean processing on content and bioaccessibility of folate, vitamin $\mathrm{B}_{12}$ and isoflavones in tofu and tempe. Food Chemistry, 141, 2418-2425.

Mo, H.-Z., Zhu, Y., \& Nout, M. J. R. (2012). In vitro digestion enhances anti-adhesion effect of tempe and tofu against Escherichia coli. Letters in Applied Microbiology, 54, 166-168.

Mohammadi, R., \& Mortazavian, A. M. (2011). Review article: technological aspects of prebiotics in probiotic fermented milks. Food Reviews International, 27, 192-212.

Mornar, A., Sertić, M., \& Nigović, B. (2013). Development of a rapid LC/DAD/FLD/MSn method for the simultaneous determination of monacolins and citrinin in red fermented rice products. Journal of Agricultural and Food Chemistry, 61, 1072-1080.

Murooka, Y., \& Yamshita, M. (2008). Traditional healthful fermented products of Japan. Journal of Industrial Microbiology and Biotechnology, 35, 791-798. 
Nam, Y. D., Lee, S. Y., \& Lim, S. I. (2012). Microbial community analysis of Korean soybean pastes by next-generation sequencing. International Journal of Food Microbiology, 155, 36-42.

Nout, M. J. R., Bakshi, D., \& Sarkar, P. K. (1998). Microbiological safety of kinema, a fermented soya bean food. Food Control, 9, 357-362.

Nout, M. J. R., Beernink, G., \& Bonants-Van Laarhoven, T. M. G. (1987). Growth of Bacillus cereus in soyabean tempeh. International Journal of Food Microbiology, 4, 293-301.

Nout, M. J. R., De Dreu, M. A., Zuurbier, A. M., \& Bonants-Van Laarhoven, T. M. G. (1987). Ecology of controlled soyabean acidification for tempe manufacture. Food Microbiology, $4,165-172$.

Nout, M. J. R., \& Kiers, J. L. (2005). Tempe fermentation, innovation and functionality: up-date into the 3rd millenium. Journal of Applied Microbiology, 98, 789-805.

Nout, M. J. R., Lee, C.-H., \& Han, B.-Z. (2014). Asian foods. In C. W. Bamforth \& R. E. Ward (Eds.), The Oxford handbook of food fermentations (pp. 557-632). New York: Oxford University Press.

Nout, M. J. R., Martoyuwono, T. D., Bonné, P. C. J., \& Odamtten, G. T. (1992). Hibiscus leaves for the manufacture of Usar, a traditional inoculum for tempe. Journal of the Science of Food and Agriculture, 58, 339-346.

Nout, M. J. R., \& Rombouts, F. M. (1990). A review: recent developments in tempe research. Journal of Applied Bacteriology, 69, 609-633.

O'Toole, D. (1999). Characteristics and use of okara, the soybean residue from soy milk production - a review. Journal of Agricultural and Food Chemistry, 47, 363-371.

Okada, N. (1989). Role of microorganisms in tempeh manufacture. Isolation of vitamin $\mathrm{B}_{12}$ producing bacteria. Japan Agricultural Research, 22, 310-316.

Partida Martinez, L. P., de Looss, C. F., Ishida, K., Ishida, M., Roth, M., Buder, K., et al. (2007). Rhizonin, the first mycotoxin isolated from the zygomycota, is not a fungal metabolite but is produced by bacterial endosymbionts. Applied and Environmental Microbiology, 73, 793-797.

Pattanagul, P., Pinthong, R., Phianmongkhol, A., \& Tharatha, S. (2008). Mevinolin, citrinin and pigments of adlay angkak fermented by Monascus sp. International Journal of Food Microbiology, 126, 20-23.

Peres, C. M., Peres, C., Hernández-Mendoza, A., \& Malcata, F. X. (2012). Review on fermented plant materials as carriers and sources of potentially probiotic lactic acid bacteria - with an emphasis on table olives. Trends in Food Science and Technology, 26, 31-42.

Rhyu, M. R., \& Kim, E. Y. (2011). Umami taste characteristics of water extract of Doenjang, a Korean soybean paste: low-molecular acidic peptides may be a possible clue to the taste. Food Chemistry, 127, 1210-1215.

Röling, W. F. M., Apriyantono, A., \& Van Verseveld, H. W. (1996). Comparison between traditional and industrial soy sauce (kecap) fermentation in Indonesia. Journal of Fermentation and Bioengineering, 81, 275-278.

Rombouts, F. M., \& Nout, M. J. R. (1989). Tempeh research in the Netherlands. In H. G. Ang, B. H. Nga, \& K. K. Lim (Eds.), Trends in food biotechnology (pp. 218-220). Singapore: Singapore Institute of Food Science and Technology.

Rose, A. H. (Ed.). (1982). Fermented foods. London: Academic Press.

Roubos-van den Hil, P. J., Dalmas, E., Nout, M. J. R., \& Abee, T. (2010). Soya bean tempe extracts show antibacterial activity against Bacillus cereus cells and spores. Journal of Applied Microbiology, 109, 137-145.

Roubos-van den Hil, P. J., Nout, M. J. R., Beumer, R. R., van der Meulen, J., \& Zwietering, M. H. (2009). Fermented soya bean (tempe) extracts reduce adhesion of enterotoxigenic Escherichia coli to intestinal epithelial cells. Journal of Applied Microbiology, 106, 1013-1021. 
Roubos-Van Den Hil, P. J., Schols, H. A., Nout, M. J. R., Zwietering, M. H., \& Gruppen, H. (2010). First characterization of bioactive components in soybean tempe that protect human and animal intestinal cells against enterotoxigenic Escherichia coli (ETEC) infection. Journal of Agricultural and Food Chemistry, 58, 7649-7656.

Sarkar, P. K., Hasenack, B., \& Nout, M. J. R. (2002). Diversity and functionality of Bacillus and related genera isolated from spontaneously fermented soybeans (Indian kinema) and locust beans (African soumbala). International Journal of Food Microbiology, 77, $175-186$.

Sarkar, P. K., Tamang, J. P., Cook, P. E., \& Owens, J. D. (1994). Kinema - a traditional soybean fermented food: proximate composition and microflora. Food Microbiology, 11, 47-55.

Scholer, H. J., \& Müller, E. (1971). Taxonomy of the pathogenic species of Rhizopus. 7th annual meeting of the British Society for Mycopathology (p. 37), Edinburgh, April, 1971.

Shurtleff, W., \& Aoyagi, A. (2001a). The book of miso. Berkeley, Toronto: Ten Speed Press.

Shurtleff, W., \& Aoyagi, A. (2001b). The book of tempeh, a cultured soyfood. Berkeley, Toronto: Ten Speed Press.

Soenarto, Y., Sudigbia, I., Hermana, H., Karmini, M., \& Karyadi, D. (1997). Antidiarrheal characteristics of tempe produced traditionally and industrially in children aged 6-24 months with acute diarrhea. In S. Sudarmadji, S. Suparmo, \& S. Raharjo (Eds.), International tempe symposium (pp. 174-186). Bali, Indonesia: Indonesian Tempe Foundation, Jakarta, Indonesia.

Steinkraus, K. H. (Ed.). (1989). Industrialization of indigenous fermented foods. New York: Marcel Dekker, Inc.

Steinkraus, K. H. (1996). Handbook of indigenous fermented foods. New York: Marcel Dekker, Inc.

Thanh, N. V., \& Nout, M. J. R. (2004). Dormancy, activation and viability of Rhizopus oligosporus sporangiospores. International Journal of Food Microbiology, 92, 171-179.

Wang, C. T., Ji, B. P., Li, B., Nout, M. J. R., Li, P. L., Ji, H., et al. (2006). Purification and characterization of a fibrinolytic enzyme of Bacillus subtilis DC33, isolated from Chinese traditional Douchi. Journal of Industrial Microbiology and Biotechnology, 33, 750-758.

Wei, Q., \& Chang, S. K. C. (2004). Characteristics of fermented Natto products as affected by soybean cultivars. Journal of Food Processing and Preservation, 28, 251-273.

WHO.2012). Guideline: Sodium intake for adults and children. Geneva: World Health Organisation.

Wicklow, D. T., McAlpin, C. E., \& Yeoh, Q. L. (2007). Diversity of Aspergillus oryzae genotypes (RFLP) isolated from traditional soy sauce production within Malaysia and Southeast Asia. Mycoscience, 48, 373-380.

Wood, B. J. B. (1982). Soy sauce and miso. In A. H. Rose (Ed.), Economic microbiology Fermented foods. Vol. 7. (pp. 39-87). London: Academic Press.

Wood, B. J. B., Adams, M. R., Vaughn, R. H., Galloway, J. H., Crawford, R. J. M., Oberman, H., et al. (1985). Microbiology of fermented foods. Vol. 1. ISBN 0-85334332-2, xx +386 pp.

Wood, B. J. B., Beddows, C. G., Luecke, F. K., Carr, J. G., Odunfa, S. A., Stanton, W. R., et al. (1985). Microbiology of fermented foods. Vol. 2. ISBN 0-85334-333-0, xx + 306 pp.

Yan, Y., Wolkers-Rooijackers, J., Nout, M. J. R., \& Han, B. (2013). Microbial diversity and dynamics of microbial communities during back-slop soaking of soybeans as determined by PCR-DGGE and molecular cloning. World Journal of Microbiology and Biotechnology, 29, 1969-1974.

Yanfang, Z. (2010). Biochemical changes in low-salt solid-state fermented soy sauce. African Journal of Biotechnology, 9, 8215-8221. 
Zhang, J. H., Tatsumi, E., Fan, J. F., \& Li, L. T. (2007). Chemical components of Aspergillus-type Douchi, a Chinese traditional fermented soybean product, change during the fermentation process. International Journal of Food Science and Technology, 42, 263-268.

Zhao, J. X., Dai, X. J., Liu, X. M., Chen, H. Q., Tang, J., Zhang, H., et al. (2009). Changes in microbial community during Chinese traditional soybean paste fermentation. International Journal of Food Science and Technology, 44, 2526-2530. 